\section{United States Awards for Further Study by Science Teachers}

THE National Science Foundation, Washington, D.C., is offering a new programme of fellowships for improving the teaching of science, mathematics and engineering in American colleges and universities. About a hundred fellowships will be awarded next March to eitizens of the United States who hold a baccalaureate degree or its equivalent, have demonstrated ability and special aptitude for teaching science, have taught full-time at the collegiate level for not less than three years, and who intend to continue teaching. Selection will be based on letters of recommendation, academic records, and other appropriate evidence of professional activity and competence. The value of the fellowships will vary, but the total income must not exceed 10,000 dollars a year ; travelling and other expenses will be allowed. Fellows may study for 3-15 months at any accredited non-profit institution of higher education in the United States or abroad. Application must be made before January 14 to the Division of Scientific Personnel and Education, National Science Foundation, Washington 25, D.C., from which further information can be obtained.

\section{University of Hull}

IT is announced from the University of Hull that Prof. E. B. Castle, professor of education and director of the Institute of Education, has been appointed pro-vice-chancellor for a period of three years. Dr. Paul Galambos has been appointed lecturer in statistics in the Department of Economics and Commerce. Mr. B. Thomas has been appointed to a research studentship in the Department of Physics for work on radiation damage. The Medical Research Council has made a grant of $£ 600$ per annum for a period of three years to assist research work on the biosynthesis of the alkaloids of plants in the Department of Botany under the direction of Dr. B. T. Cromwell ; Mr. K. Rothwell has been appointed to a research assistantship in the Department to undertake this work. The Research Section of the Shell Petroleum Company has made a grant of $£ 1,000$ to finance a research appointment in the Chemistry Department over a period of two years from the session $1957 / 58$.

\section{University of London}

THE following announcements have been made by the University of London: Dr. I. M. P. Dawson, lecturer in pathology in the University of Leeds, has been appointed to the University readership in pathology tenable at Westminster Medical School. The title of reader in physiology has been conferred on Mr. R. D. M. I.-K. Harkness in respect of his post at University College, and that of reader in mathematics on Dr. K. F. Roth, in respect of his post at University College.

\section{Announcements}

DR. O. G. S. CRAWFORD, founder and editor since 1927 of Archoeology, and formerly archæology officer of the Ordnance Survey, has been awarded the Verdienstkreuz (first class) of the Federal German Republic, for his services to archæology.

Prof. T. S. WheELer, professor of chemistry in University College, Dublin, will be going to the United States on a lecture tour during JanuaryMarch 1957.
Mr. George Brearlex, a partner of Cremer and Brearley, consulting chemical engineers, and formerly managing director of Brotherton and Co., Ltd., has been appointed director of the Association of British Ghemical Manufacturers in succession to Mr. J. Davidson Pratt, who is retiring in June 1957.

The Ministry of Supply announces that Dr. A. W. Lines has been promoted to deputy chief scientific officer and appointed senior superintendent, Research and Assessment Division, Guided Weapons Department, Royal Aircraft Establishment, Farnborough.

THe following officers and new members of council for 1956-57 of the Institution of Civil Engineers have been announced: President, H. J. F. Gourley; Vice-Presidents, Sir Arthur Whitaker, Prof. A. J. S. Pippard, A. C. Hartley, Sir Herbert Manzoni ; New Members of Council, R. J. Ashby, J. F. A. Baker, F. E. P. Clear, D. K. Duff, J. E. Dumbleton, Dr. L. F. Loder, F. J. Oliver and W. L. Owen.

The Royal Agricultural Society of England offers annually a medal together with an award of one hundred guineas for research work of outstanding merit carried out in the United Kingdom which has proved, or is likely to prove, of benefit to agriculturo. Recommendations for the next award, by the heads of university departments, research stations and institutes and other research establishments, must be submitted to the Secretary, Royal Agricultural Society of England, 35 Belgrave Square, London, S.W.1, not later than January 31, 1957.

Prof. V. B. Wrgalesworth, Quick professor of biology in the University of Cambridge and director of the Agricultural Research Council Unit of Inseot Physiology, will deliver the fourth Middleton Memorial Lecture in the Wellcome Building, 183 Euston Road, London, N.W.1, on December 6, at 5.30 p.m. He will speak on "Insects and the Farmer".

THe Institution of Naval Architects is offering the following scholarships, which are tenable for three or four years, according to the length of the course at the university or college selected: Trewent (naval architecture), £175 per annum; age limit, twenty. Parsons and Yarrow (marine engineering), each $£ 175$ per annum; age limit, twenty-one. All three are limited to British subjects. Further particulars can be obtained from the Secretary, Institution of Naval Architects, 10 Upper Belgrave Street, London, S.W.1.

THE autumn meeting of the Physical Society is being held this year in the Department of Natural Philosophy, University of Edinburgh, during December 17-19, and the general theme is " $\beta$ - and $\gamma$-Ray Spectroscopy and Related Topics". During the meeting, on December 18, Prof. P. I. Dee, of the University of Glasgow, will deliver the eighth Rutherford Memorial Lecture of the Society; he will speak on "The $\alpha$-Particle".

The first Technical Convention of the Institution of Telecommunication Engineers (New Delhi) will be held on December 30 at the National Institute of Sciences Hall in New Delhi. It will be preceded by the annual general meeting of the Institution on December 29, when Brig. Iyappa, the retiring president, will induct the president-elect, Prof. $K$. Sreenivasan, head of the Department of Electrical Communication Engineering, Indian Institute of Science, Bangalore.

The Institution of Chemical Engineers has now moved to 16 Belgrave Square, London, S.W.1. 